\title{
Influence of Treated Rapeseed Meal on Growth Performance, Nutrient Digestibility and Blood Profile in Growing Pigs
}

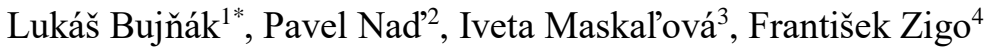 \\ ${ }^{1}$ Department of Animal Nutrition and Husbandry, University of Veterinary Medicine and Pharmacy \\ Košice, Slovakia \\ *Corresponding author's email: lukas.bujnak [AT] uvlf.sk \\ ${ }^{2}$ Department of Animal Nutrition and Husbandry, University of Veterinary Medicine and Pharmacy \\ Košice, Slovakia \\ Email: pavel.nad [AT] uvlf.sk \\ ${ }^{3}$ Department of Animal Nutrition and Husbandry, University of Veterinary Medicine and Pharmacy \\ Košice, Slovakia \\ Email: iveta.maskalova [AT] uvlf.sk \\ ${ }^{4}$ Department of Animal Nutrition and Husbandry, University of Veterinary Medicine and Pharmacy \\ Košice, Slovakia \\ Email: frantisek.zigo [AT] uvlf.sk
}

\begin{abstract}
This study was conducted to investigate the influence of replacing part of soybean meal (SBM) with $15 \%$ treated rapeseed meal (tRSM) on growth performance, blood parametres and nutrient digestibility in young growing pigs. A total of 12 crossbred growing pigs (Slovakian White $x$ Landrace) with an average initial body weight of $15.70 \pm 1.83 \mathrm{~kg}$ were divided into two dietary treatments according to their body weight and sex (six pigs in each group). The experiment lasted 34 days. The rapeseed meal was treated with the product that neutralizes the negative effects of glucosinolates contained in rapeseed by-products for pigs feeding. In the our study, we did not observe negative effects of tRSM on body weight, average daily gain and feed conversion ratio. In blood profile, serum urea, albumin, glucose and total chlosterol were not influenced by dietary tRSM treatment. Concentration of total proteins was decreased at the end of the experimental period in the experimental group $(P<0.01)$. For apparent total tract digestibility acidinsoluble ash was used as marker. Partially replacing of SBM with tRSM had no significant negative effects on the apparent total tract digestibility of dry matter, crude protein and crude fat. Finally, the inclusion of $15 \%$ of treated RSM in growing pig diets had no negative effects on growth performance, nutrients digestibility and selected blood characteristics.
\end{abstract}

Keywords— pigs, rapeseed meal, growth performance, digestibility, blood characteristics

\section{INTRODUCTION}

European pig production, including Slovak republic, is to large extent based on imported protein feed sources such as soybean meal (SBM). Globally, SBM is the most common protein source in pig diets [1]. Because of its balanced amino acids content and high concentration of protein, SBM is generally considered a good protein source for non-ruminnat livestock diets [2].

In some European countries, where soybeans are a low yielding crop, the interest has been directed towards protein sources grown in Europe, such as rapeseed by-products, as an alternative to soybean meal. Rapeseed meal (RSM) has a lower content of protein and certain amino acids - mainly lysine, and increased crude fiber content compared to soybean meal. Although lysine content of RSM is lower than SBM, sulphur containing amino acids such as cysteine and methionine are much higher. RSM is a co-product in oil and biofuel production, it is abundant and cheap and can serve as an alternative to SBM in diets for monogastric animals [3].

The using of these rapeseed meals is limited due to the presence of anti-nutritional factors in the form of mainly glucosinolates and erucic acid. Various technological procedures are used to reduce these unfavourable properties [4]. Several studies have been carried out on rapeseed meal with low concentrations of anti-nutritional factors as a alternative protein source with different nutritional characteristics in pig diets using different methodologies.

The effect of rapeseed meal in pig diets may be dependent on many of factors, such as new varieties of rapeseed, chemical characteristics, diet formulation, inclusion level and replacement strategy, amino acid or enzyme supplementation, methods used for treating of rapeseed meal, diet processing, and feeding methods applied [1]. Different processing of meals and also 
diets may generate variation in nutritional value, digestible essential amino acids and contents of glucosinolates [5; 6] and this could partially explain variable responses in pig performance among different studies.

Therefore, the objective of this experiment was to evaluate whether 15\% treated rapeseed meal (tRSM) can partially replace soybean meal (SBM) as a main protein source in growing pig diets. The double-low rapeseed (00-rapeseed) with low concentrations of glucosinolates and erucic acid was used in our study.

\section{MATERIAL AND METHOD}

Twelve crossbred piglets (Slovakian White $\times$ Landrace) with an average body weight (BW) of $15.70 \pm 1.83 \mathrm{~kg}$ were used for a 34-day trial. Pigs were divided into two groups (6 pigs in each group). Both groups contained equal numbers of gilts (2) and barrows (4). The same basic ingredients for the control and the experimental groups were used in the study.

The diets were formulated based on cereal grains (corn, wheat and barley), soybean meal or treated rapeseed meal, vitamin + mineral premix and synthetic amino acids. Both diets had similar crude protein $(\mathrm{CP})$ content. Dietary treatments were as follows: control, a SBM-based diet and experimental, a treated RSM-based diet (+15\% tRSM; partial replacement of soybean meal). The rapeseed meal was treated with 2.5\% LinaropAgri® LRA (LINAGRI s.r.o., Czechia), the product, which may reduce a negative effect of glucosinolates and therefore may improve the digestibility of rapeseed meal.

The nutritional characteristics of the treated RSM $(97.5 \%$ rapeseed meal $+2.5 \%$ LRA) were the following: dry matter $897 \mathrm{~g} / \mathrm{kg}$, crude protein $349 \mathrm{~g} / \mathrm{kg}$, ether extract $16.1 \mathrm{~g} / \mathrm{kg}$ and crude fibre $122 \mathrm{~g} / \mathrm{kg}$ as fed basis. The declared content of glucosinolates in the used rapeseed meal samle was max. $20 \mu \mathrm{mol} / \mathrm{g}$. All diets met or exceeded the requirements of NRC [7]. Composition, analyzed and calculated nutrient content of diets are shown in Table 1. All animals were fed twice per day and pigs were given free access to water.

Individual body weight of pigs and feed consumption on a group basis were recorded at the beginning and end of the experiment to calculate average daily gain (ADG) and feed conversion ratio (FCR). The study was carried out in the animal quarters of the Department of Animal Nutrition and Husbandry at the University of Veterinary Medicine and Pharmacy in Košice in compliance with the EU regulations concerning the welfare of animals.

Table 1: Ingredient composition, analyzed and calculated nutrient content of control and experimental diet in growing period (as-fed basis)

\begin{tabular}{l|c|c}
\hline Ingredients(\%) & Control diet & Experimental diet \\
\hline Corn & 24 & 30 \\
Wheat & 20.64 & 25.73 \\
Barley & 32 & 16 \\
SBM, CP 46\% & 20 & 10 \\
tRSM & & 15 \\
Premix Vitamin-Minerals & 3 & 3 \\
Lysine & 0.2 & 0.2 \\
Methionine & 0.08 & \\
Threonine & 0.08 & 0.07 \\
\hline Analyzed content $(\mathrm{g} / \mathrm{kg})$ & & \\
\hline Dry matter & 884.6 & 886.3 \\
Crude protein & 172.85 & 172.81 \\
Crude fat & 19.98 & 22.56 \\
Crude fiber & 37.59 & 45.55 \\
\hline Calculated content $(\mathrm{g} / \mathrm{kg})$ & & \\
Lysine & 11.90 & 11.92 \\
Threonine & 7.21 & 7.26 \\
Methionine+cysteine & 6.50 & 6.66 \\
Metabolizable energy $(\mathrm{MJ} / \mathrm{kg})$ & 12.88 & 12.80 \\
\hline SBM & & \\
\hline
\end{tabular}

SBM - soybean meal; tRSM - treated rapeseed meal; CP - crude protein 
The diets were analysed for their dry mater (DM), crude protein (CP), crude fiber and crude fat according to the EC Commission Regulation [8]. The amino acids content in both diets were calculated according to their requirements of limiting amino acids [7]. Blood samples were obtained from the cranial vena cava of both groups at the end of the experimental period (day 34). The serum parameters were determined using a fully automatic random access benchtop analyser Ellipse (Italy). The faeces were taken directly from the rectum at the end of the investigation. For apparent fecal digestibility determination acid-insoluble ash was used as marker. Fecal samples were analyzed for dry matter, crude protein and crude fat.

All data were reported as the mean \pm standard deviation. The differences between means were determined according to the unpaired t-test using Graph-Pad Prism statistical program (Graph Prism software, USA). By conventional criteria, differences $(\mathrm{P}<0.05)$ were considered to be statistically significant.

\section{RESULTS AND DISCUSSION}

Body weights at the end the trial were not significantly affected by dietary inclusion of $15 \%$ treated RSM as partial replacement to SBM. During the experimental period, ADG was slightly higher in pigs fed the experimental diet than those fed the control diet, but there were no statistically significant differences in ADG between groups ( $P>0.05)$. The FCR was a little poorer in pigs fed the control diet $(+0.03 \mathrm{~kg}$ feed $/ \mathrm{kg}$ gain) $($ Table 2$)$.

The coefficient of fecal digestibility of DM, CP and crude fat was higher (dry matter $+2.42 \%$; crude protein $+2.29 \%$; crude fat $+0.34 \%$ ) in pigs from the control group (SBM-based diet) compared to pigs from the experimental group (tRBMbased diet). However, differences for the apparent fecal digestibility of DM, CP and crude fat were not statistically significant in the our study (Table 2).

Table 2: Influence of dietary treated rapeseed meal on growth performance and nutrient digestibility in growing pigs

\begin{tabular}{l|c|c}
\hline & Control group & Experimental group \\
Number of pigs & 6 & 6 \\
\hline Body weight $(\mathrm{kg})$ & $15.80 \pm 1.88$ & $15.58 \pm 1.79$ \\
Initial & $40.70 \pm 3.69$ & $41.05 \pm 3.42$ \\
End of trial & $732.9 \pm 93.9$ & $752.0 \pm 93.0$ \\
\hline ADG $(\mathrm{g})$ & 1.88 & 1.85 \\
FCR $(\mathrm{kg}$ feed / kg gain) & & \\
\hline Nutrient digestibility $(\%)$ & $85.86 \pm 1.98$ & $83.44 \pm 2.07$ \\
Dry matter & $84.14 \pm 2.22$ & $81.85 \pm 1.87$ \\
Crude protein & $69.21 \pm 2.92$ & $68.87 \pm 2.32$ \\
Crude fat & & \\
\hline
\end{tabular}

ADG - Average daily gain; FCR - Feed conversion ratio

Serum total protein concentration was decreased at the end of the experimental period in the experimental group compared to the control group $(\mathrm{P}<0.01)$. Serum albumin, urea, glucose and cholesterol concentration was not affected by the dietary tRSM supplementation (Table 3). The detected mean values of analyzed parameters in blood serum of pigs from both groups were within the reference values according to Kraft and Dürr [9].

Table 3: Influence of dietary treated rapeseed meal (tRSM) on blood profiles of growing pigs

\begin{tabular}{l|c|c|c}
\hline Parameters & Reference values* & Control group & Experimental group \\
\hline Total proteins (g/l) & $<86$ & $71.73 \pm 2.67^{\mathrm{a}}$ & $66.96 \pm 1.59^{\mathrm{b}}$ \\
Albumin (g/l) & $18-31$ & $33.58 \pm 2.37$ & $31.81 \pm 3.01$ \\
Urea (mmol/l) & $3.3-8.3$ & $4.19 \pm 0.52$ & $4.33 \pm 0.30$ \\
Glucose (mmol/l) & $3.9-6.4$ & $5.56 \pm 0.33$ & $5.46 \pm 0.25$ \\
Cholesterol (mmol/l) & $2-3.3$ & $2.18 \pm 0.29$ & $2.02 \pm 0.14$ \\
\hline
\end{tabular}

$\mathrm{a}, \mathrm{b}$ - significant differences $(\mathrm{P}<0.01)$; *according to Kraft and Dürr [9] 
In several previous experiments, it has been demonstrated that between 15\% and 30\% rapeseed meal can be included in diets fed to growing-finishing pigs without impairing growth performance $[10 ; 11]$. Also Yun et al. [12] reported that the inclusion of $4 \%$ of RSM in finishing pig diets had no negative effects on growth performance, nutrients digestibility and blood characteristics (Blood urea nitrogen and Creatinine).

Choi et al. [13] observed that RSM could be supplemented to growing-finishing diets up to $9 \%$ without detrimental effects on growth performance of growing-finishing pigs. The RSM, used in their experiment was supplemneted to the diets with replacement of corn, SBM and soy oil.

The meta-analyses of Hansen et al. [1] showed no differences in ADG, and feed:gain of using a double-low rapeseed (00-rapeseed or canola meal) with low concentrations of glucosinolates and erucic acid in diets for weanling pigs and a minor reduction in overall effects size of ADG and gain:feed in growing-finishing pigs.

It is well known that RSM has higher fibre content that affects nutrient digestibility [14]. Many researchers have attempted to enhance the nutrient digestibility of RSM through decreasing fibre content and anti-nutritional factors such as glucosinolates by improving processing methods $[15 ; 16]$. Nutrient digestibility is influenced by a number of factors including the fiber from rapeseed hulls, anti-nutritional factors (tannins, erucic acid, and glucosinolates) and dietary formulation [17]. However, in the present study, inclusion of $15 \%$ tRSM did not affect nutrient digestibility significantly.

\section{CONCLUSION}

Our results suggest that treated RSM (with the product that suppresses the negative effects of glucosinolates) can be used as an alternative feed source without adverse effects on growth performance, serum parameters and nutrient digestibility if used in well-balanced diet for young growing pigs.

\section{CONFLICTS OF INTERESTS}

Authors declare that there are no conflicts of interest.

\section{ACKNOWLEDGEMENT}

This work was supported by the project KEGA no. 006UVLF-4-2020.

\section{REFERENCES}

[1] Hansen, J. Ø., Øverland, M., Skrede, A., Anderson, D. M., Collins, S. A. (2020). “A meta-analysis of the effects of dietary canola/double low rapeseed meal on growth performance of weanling and growing-finishing pigs". Animal Feed Science and Technology, 259, 114302.̌̆

[2] Kim, I. H., Hancock, J. D., Jones, D. B., Reddy, P. G. (1999). "Extrusion processing of low-inhibitor soybeans improves growth performance of early-weaned pigs". Asian-Australasian Journal of Animal Sciences, 12(8), 12511257.

[3] Skugor, A., Kjos, N. P., Sundaram, A. Y., Mydland, L. T., Ånestad, R., Tauson, A. H., Øverland, M. (2019). "Effects of long-term feeding of rapeseed meal on skeletal muscle transcriptome, production efficiency and meat quality traits in Norwegian Landrace growing-finishing pigs". PloS one, 14(8), e0220441.

[4] Grela, E. R., Czech, A., Kiesz, M., Wlazło, Ł., Nowakowicz-Dębek, B. (2019). “A fermented rapeseed meal additive: Effects on production performance, nutrient digestibility, colostrum immunoglobulin content and microbial flora in sows". Animal Nutrition, 5(4), 373-379.

[5] Adewole, D. I., Rogiewicz, A., Dyck, B., Slominski, B. A. (2016). "Chemical and nutritive characteristics of canola meal from Canadian processing facilities". Animal Feed Science and Technology, 222, 17-30.

[6] Wang, L. F., Beltranena, E., Zijlstra, R. T. (2017). "Diet nutrient digestibility and growth performance of weaned pigs fed Brassica napus canola meal varying in nutritive quality". Animal Feed Science and Technology, 223, 90-98.

[7] NATIONAL RESEARCH COUNCIL (2012). Nutrient Requirements of Swine. 11th rev. ed. Washington: National Academies Press. 400 pp.

[8] EUROPEAN COMMISSION. Commission Regulation (EC) No 152/2009 of 27 January 2009 laying down the methods of sampling and analysis for the official control of feed. Off. J. Eur. Union. 2009, 54, 1-130.

[9] Kraft, W. and Dürr, M. U. (2001). 30. Reference values. In Hajko \& Hajková: Clinical Laboratory Diagnosis in Veterinary Medicine (Slovak/Czech edition). Bratislava: VEDA. 365 pp.

[10] King, R. H., Eason, P. E., Kerton, D. K., Dunshea, F. R. (2001). "Evaluation of solvent-extracted canola meal for growing pigs and lactating sows". Australian Journal of Agricultural Research, 52(10), 1033-1041. 
[11] Seneviratne, R. W., Young, M. G., Beltranena, E., Goonewardene, L. A., Newkirk, R. W., Zijlstra, R. T. (2010). “The nutritional value of expeller-pressed canola meal for grower-finisher pigs". Journal of Animal Science, 88(6), 20732083.

[12] Yun, H. M., Lei, X. J., Lee, S. I., Kim, I. H. (2018). "Rapeseed meal and canola meal can partially replace soybean meal as a protein source in finishing pigs". Journal of Applied Animal Research, 46(1), 195-199.

[13] Choi, H. B., Jeong, J. H., Kim, D. H., Lee, Y., Kwon, H., Kim, Y. Y. (2015). "Influence of rapeseed meal on growth performance, blood profiles, nutrient digestibility and economic benefit of growing-finishing pigs". AsianAustralasian Journal of Animal Sciences, 28(9), 1345-1353.

[14] Landero, J. L., Beltranena, E., Cervantes, M., Morales, A., Zijlstra, R. T. (2011). "The effect of feeding solventextracted canola meal on growth performance and diet nutrient digestibility in weaned pigs". Animal Feed Science and Technology, 170(1-2), 136-140.

[15] Liu, Y., Song, M., Maison, T., Stein, H. H. (2014). "Effects of protein concentration and heat treatment on concentration of digestible and metabolizable energy and on amino acid digestibility in four sources of canola meal fed to growing pigs". Journal of Animal Science, 92(10), 4466-4477.

[16] Sanjayan, N., Heo, J. M., Nyachoti, C. M. (2014). "Nutrient digestibility and growth performance of pigs fed diets with different levels of canola meal from Brassica napus black and Brassica juncea yellow". Journal of Animal Science, 92(9), 3895-3905.

[17] McDonnell, P., O'Shea, C., Figat, S., O'Doherty, J. V. (2010). "Influence of incrementally substituting dietary soya bean meal for rapeseed meal on nutrient digestibility, nitrogen excretion, growth performance and ammonia emissions from growing-finishing pigs". Archives of Animal Nutrition, 64(5), 412-424. 